\title{
НЕЙРОМЕРЕЖЕВЕ МОДЕЛЮВАННЯ ЗАЛЕЖНОСТЕЙ РЕЗУЛЬТАТІВ ВИПРОБУВАНЬ ГАЗОТУРБІННИХ АВІАДВИГУНІВ
}

\author{
Субботін С. О. ${ }^{1}$, Корнієнко О. В. ${ }^{2}$ \\ 1,2々апорізький національний технічний університет, м. Запоріжжя \\ E-mail: ${ }^{1}$ subbotin@zntu.edu.ua, ${ }^{2}$ al.korn95@gmail.com
}

Copyright (C) 2017 by author and the journal "Automation technological and business - processes". This work is licensed under the Creative Commons Attribution International License (CC BY). http://creativecommons.org/licenses/by/4.0/

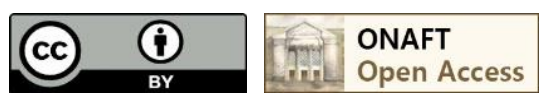

Анотація: Роботу присвячено вирішенню актуального завдання створення математичного забезпечення для побудови моделей кількісних залежностей на основі багатошарових нейронних мереж та виріменню за його допомогою практичної задачі моделювання залежностей параметрів процесу роботи авіаційних двигунів під час їх випробувань.

Запропоновано метод побудови глибоких нейронних мереж прямого потирення, який використовує коригувальну нейронну мережу для покращення результатів роботи звичайної нейромережі. Пропонована архітектура нейромережі складається з двох блоків-нейромереж: перший - чотиришарова нейромережа прямого поширення, другий - нейронна мережа, що виправляє результати роботи першої. Для иього значення виходу першої мережі передається на вхід другої разом із вхідними параметрами. При иььому для збільшення точності для кожного вихідного параметра будується окрема модель. Кожна з нейронних мереж навчається окремо, щзо дозволяє спростити та прискорити процес навчання. Навчання пропонованої нейромережі пропонується проводити на основі градієнтного методу та техніки зворотного поширення помилки. У процесі навчання мінімізується функція помилки мережі, яка визначає різницю між виходами мережі $і$ реальними значеннями. Для збільшення точності моделі, побудованої на основі гібридної нейромережі із коригувальним блоком, пропонується виконувати відбір інформативних ознак шляхом послідовного видалення найменш інформативних ознак, доки помилка нейронної мережі не збільшиться від чергового видалення ознаки. Для прискорення відбору доцільно використовувати зменшену кількість епох навчання та не використовувати коригувальну нейронну мережу.

Розроблено програмне забезпечення, яке реалізує запропонований метод і дозволяє виконувати побудову нейронних мереж, їх навчання та тестування на вибірках даних; вирішено практичне завдання визначення значень параметрів авіаційних двигунів при проведені їх випробувань.

Abstract: The work is devoted to solving the actual problem of creating mathematical support for constructing quantitative dependency models based on multilayer neural networks and solving the practical problem of modeling the dependences of the parameters of the process of operation of aircraft engines during their testing on its basis.

The method of constructing feed-forward deep neural networks is proposed. It uses the corrective neural network to improve the results of the normal neural network.

The proposed architecture of the neural network consists of two blocks of neural networks: the first is a four-layer feedforward neural network, the second is a neural network, which corrects the results of the first network. For this, the value of the the first network output is transmitted to the second input along with the input parameters. In this case, a separate model is constructed to increase the accuracy for each output parameter. Each neural networks is trained separately, which simplifies and accelerates the training process. The training of the proposed neural network is proposed to be carried out on the basis of the gradient method and the technique of back error propagation. In the training proces, the network error function is minimized, which determines the difference between network outputs and real values. In order to increase the accuracy of the model built on the basis of the hybrid neural network with the correction block, it is proposed to select the informative features by sequentially removing the least informative features, until the error of the neural network does not increase from the next removal of the sign. To speed up the selection, it is advisable to use a reduced number of training periods and not use the corrective neural network. 


$$
\text { http://www.atbp.onaft.edu.ua/ }
$$

The software that implements the proposed method is developed. It allows to construct the neural networks, to train and test them on data samples. The practical task of determining the parameters values of air-engines during their testing is solved.

Ключові слова: Ознака, навчання, нейрон, нейронна мережа, помилка, градієнт.

Keywords: Feature, training, neuron, neural network, error, gradient.

\section{Вступ}

Проведення випробувань авіаційних двигунів пов'язане зі значними витратами, обумовленими великою вартістю пального, використовуваного для дослідження роботи авіадвигунів у різних режимах. Зокрема, випробування газотурбінних авіадвигунів проводиться у чотирьох режимах роботи: номінальному, злітному, першому та другому крейсерських $[1,2]$. Окрім витрат пального, процес випробувань авіадвигунів пов'язаний зі значними витратами часу, що в умовах обмеженої пропускної здатності випробувального центру теж підвищує на вартість випробувань та обмежує виробничі потужності підприємства.

Тому актуальною проблемою є зменшення кількості режимів і часу випробувань шляхом обчислення значень частини характеристик авіадвигунів у певних режимах випробувань через значення параметрів авіадвигунів у інших режимах випробувань. Для цього треба побудувати моделі залежностей параметрів газотурбінних авіадвигунів у різних режимах випробувань. Такі моделі не тільки дозволять зменшити витрати на випробування, але й підвищать можливості перевірки результатів випробувань авіаційних двигунів.

Оскільки процес роботи та випробування авіадвигуна характеризуються низкою параметрів, які мають різні масштаби, розмірності та подаються у різних форматах, архітектура моделі для вирішуваної проблеми повинна дозволяти обробку як дискретних, так і неперервних сигналів. 3 іншого боку, через брак аналітичних залежностей модель повинна будуватися тільки на основі експериментальних спостережень.

Одним з найбільш перспективних засобів побудови моделей за спостереженнями в умовах відсутності аналітичних залежностей $є$ штучні нейронні мережі [3], які здатні під час навчання за рахунок узагальнення видобувати знання 3 даних. Тому їх доцільно обрати як базис для побудови моделей залежностей параметрів авіадвигунів. Відомо багато різних архітектур нейронних мереж та методів їхнього навчання [4-6]. Серед них нейронні мережі прямого поширення [4] є однією з найбільш широко використовуваних та придатних до подальшого витягу знань 3 даних, що $є$ важливим для завдань діагностування, оскільки потрібно не тільки отримати прогнозоване значення вихідного параметру, але й розуміти процес його отримання. Тому для побудови моделей залежностей параметрів випробувань авіадвигунів доцільно обрати нейромережі прямого поширення. Навчання таких нейромереж, як правило, здійснюється на основі градієнтних методів та техніки зворотного поширення помилки мережі [4].

Проте, у випадку, коли використовується багатошаровий персептрон, точність отриманих результатів може бути недостатньою, тому виникає потреба у корекції результатів розрахунків нейромоделі.

Мета роботи полягає у створенні архітектури та методу навчання нейромоделі, яка буде здатна коригувати значення, отримані при використанні багатошарового персептрона.

Постановка задачі

Нехай ми маємо вибірку спостережень, де хs - вхідні параметри, уs - вихідні (залежні) параметри, що визначаються за даними випробувань авіаційних двигунів, s=1, .., Sall, де Sall - кількість екземплярів у вибірці.

Тоді задача побудови моделі залежності $\mathrm{y}=\mathrm{f}(\mathrm{w}, \mathrm{x})$ на основі нейронної мережі буде полягати в знаходженні таких значень множини вагових коефіцієнтів w, при яких буде задовільнено критерій якості моделі.

Функціонування багатошарової нейромережі прямого поширення може бути описано у такий спосіб [4]. Вхідні ознаки розпізнаваного екземпляра подаються на входи мережі та далі поширюються від вхідного шару (х1...xn) до вихідного (y1...ym). Кожен нейрон на прихованих та вихідному шарах отримує на входах сигнали 3 виходів нейронів попереднього шару. Вхідний вектор кожного нейрона перетворюється у скаляр за допомогою вагової (дискримінантної) функції, після чого значення вихідного сигналу розраховується за допомогою функції активації. Вихідні значення останнього шару є результатом роботи нейромережі.

Як критерій якості моделі використовують середньоквадратичну помилку Е, що визначається за формулою:

$$
E=\sqrt{\sum_{i=1}^{N}\left(R_{i}-M_{i}\right)^{2}}
$$

де $\mathrm{Ri}$ - реальне значення вихідного параметра , Mi - розрахункове значення параметра , отримане за допомогою моделі, i=1, ..., Y, Y - кількість вихідних параметрів моделі.

Глибока нейромережа із коригувальним блоком

Для збільшення точності синтезованих моделей на основі багатошарових нейромереж пропонується використання нейронної мережі прямого поширення із коригувальним блоком. Пропонована архітектура нейромережі складається 3 двох блоків-нейромереж: перший - чотиришарова нейромережа прямого поширення, другий - нейронна мережа, що виправляє результати роботи першої. Для цього значення виходу першої мережі передається на вхід другої разом із вхідними параметрами. При цьому для збільшення точності для кожного вихідного параметра будується окрема модель. На рис. 1 зображено схему гібридної глибокої нейронної мережі із коригувальним блоком. 
Метод навчання полягає у послідовному виконанні таких етапів.

Навчання пропонованої нейромережі пропонується проводити на основі градієнтного методу та техніки зворотного поширення помилки. У процесі навчання мінімізується функція помилки мережі , яка визначає різницю між виходами мережі i реальними значеннями. В якості функції помилки доцільно використовувати середньоквадратичну помилку Е.

Етап ініціалізації. Задати навчальну вибірку даних $<x, y>$ та структуру нейромережі. Ваговим коефіцієнтам нейронів задати випадкові значення 3 діапазону $[-0.1 ; 0.1]$. Задати: кількість циклів (епох) навчання Еросhs=0, максимальну кількість циклів (епох) навчання MaxЕpochs, крок навчання $\alpha$.

Етап нормування вибірки. Вибірка нормується шляхом відображення значень ознак на інтервал [0; 1]. Нові значення визначаються за формулою:

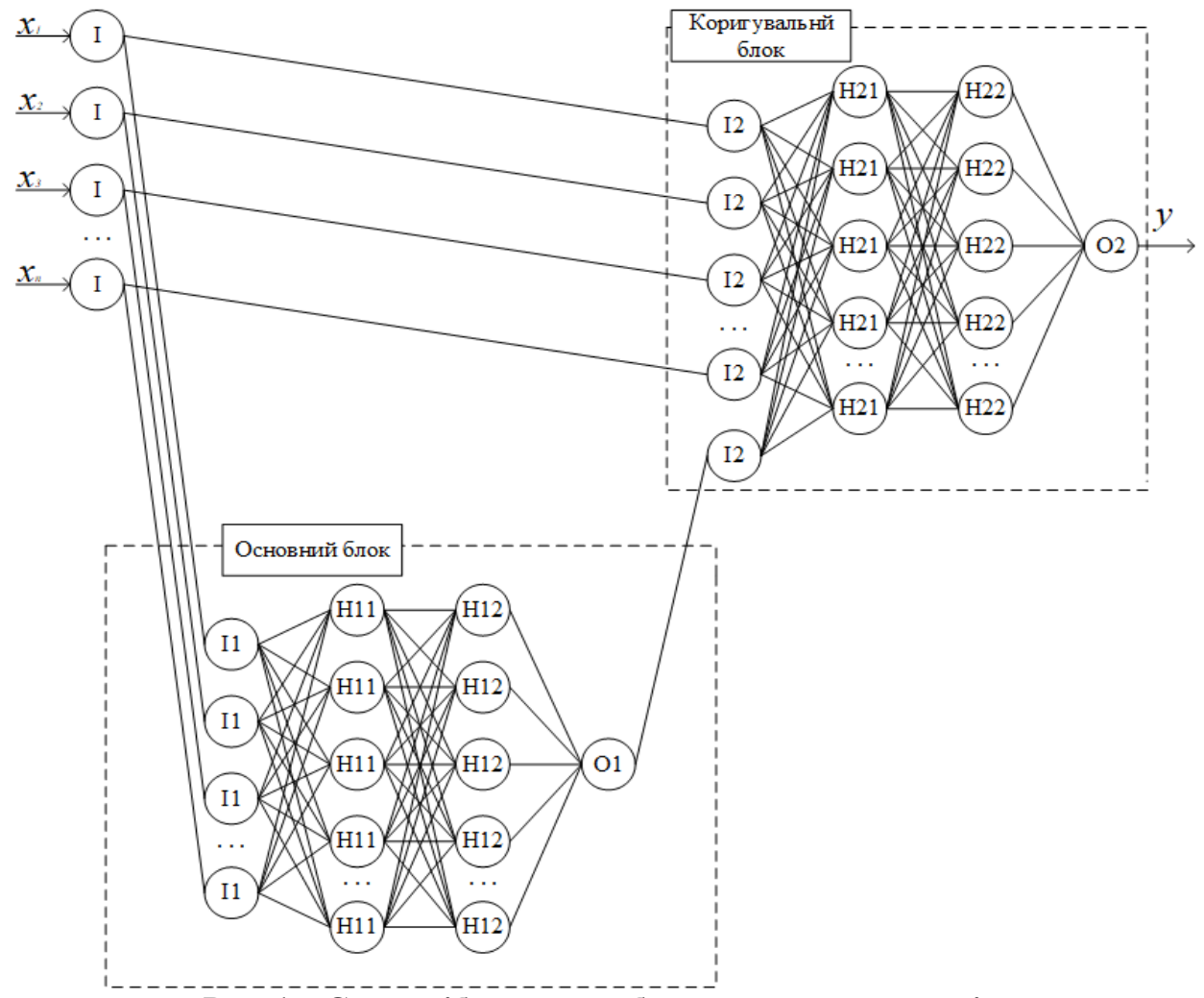

Рис. 1 - Схема гібридної глибокої нейронної мережі:

I - вхідні параметри, I1 - входи першої нейронної мережі, Н11 - перший прихований шар першої нейронної мережі, Н12 - другий прихований шар першої нейронної мережі,

01 - вихідний нейрон першої нейронної мережі, I2 - входи коригуючої нейронної мережі,

H21 - перший прихований шар другої нейронної мережі, Н22 - другий прихований шар

другої нейронної мережі, О2 - вихідний нейрон коригуючої нейронної мережі

$$
x_{i, j}^{\prime}=\frac{x_{i, j}-x_{\min , j}}{x_{\text {max }, j}-x_{\min , j}}
$$

де $\mathrm{xi,j}$ - значення j параметра для i екземпляра вибірки, хmax,j та xmin,j - максимальне та мінімальне значення j параметра серед всіх екземплярів вибірки. Аналогічно визначаються значення для вихідних параметрів у.

Етап корекції ваг. Послідовно у циклі для Epochs $=0,1, \ldots$, MaxEpochs, де MaxEpochs - максимально допустима задана кількість епох навчання, виконується навчання мережі на основі екземплярів вибірки шляхом виконання етапу навчання мережі на основі екземпляра та коректується крок навчання $\alpha$ [7].

Етап навчання мережі на основі екземплярів вибірки. Послідовно на входи нейромережі подається і-й екземпляр навчальної вибірки, $\mathrm{i}=1,2, \ldots \mathrm{Str}$, де $\mathrm{Str}$ - кількість екземплярів навчальної вибірки.

Для поточного екземпляра розраховується вихід нейронної мережі за формулою:

$$
O=\psi 3\left(w 3_{0}+\sum_{k=1}^{K} w 3_{k} \cdot \psi 2\left(w 2_{0, k}+\sum_{m=1}^{M} w 2_{m, k} \cdot \psi 1\left(w 1_{0, m}+\sum_{n=1}^{N} w 1_{n, m} \cdot I_{n}\right)\right)\right)
$$

де $\psi 1(\mathrm{x}), \psi 2(\mathrm{x}), \psi 3(\mathrm{x})$ - функції активації першого прихованого шару, другого прихованого шару і вихідного шару відповідно, w1, w2, w3 - вагові коефіцієнти першого прихованого шару, другого прихованого шару і вихідного шару відповідно, I - вхідні значення, N - кількість нейронів вхідного шару, M - кількість нейронів першого прихованого шару, К - кількість нейронів другого прихованого шару. 
http://www.atbp.onaft.edu.ua/

Після цього обчислюється середньоквадратична помилка мережі Е. Через те, що на вихідному шарі 1 нейрон, формулу помилки можна спростити до , де $\mathrm{R}$ - бажане значення виходу.

Далі обчислюється градієнт помилки нейрону вихідного шару:

Якщо як функцію активації використовувати функцію гіперболічний тангенс , то іiі похідна після спрощення матиме вигляд , а в даному випадку О - це вже обчислене значення $\tanh (\mathrm{x})$ [7].

Після цього обчислюються градієнти для нейронів прихованих шарів:

- для другого прихованого шару:

$$
G_{k}=G_{o} \cdot w 3_{k} \cdot\left(1-O u t 2_{k}^{2}\right), k=1,2, \ldots, K
$$

для першого прихованого шару:

$$
G_{m}=\sum_{k=1}^{K} G_{k} \cdot w 2_{m} \cdot\left(1-\text { Out } 1_{m}^{2}\right), m=1,2, \ldots, M,
$$

де Out1 - вихідні значення нейронів першого прихованого шару, Out2 - вихідні значення нейронів другого прихованого шару.

Далі коректуються вагові коефіцієнти:

$$
\begin{gathered}
w 1_{n, m}=w 1_{n, m}-I_{n} \cdot G_{m} \cdot \alpha, \\
w 2_{m, k}=w 2_{m, k}-\text { Out }_{m} \cdot G_{k} \cdot \alpha, \\
w 3_{k}=w 3_{k}-\text { Out }_{k} \cdot G_{o} \cdot \alpha .
\end{gathered}
$$

Після навчання першої нейронної мережі розраховуються вихідні значення для навчальної та тестової вибірок та додаються до них в якості ще одного параметра. Після цього так само навчається коригуюча нейронна мережа.

Етап контрастування нейронної мережі. Контрастування полягає у видаленні частини найменш значимих зв’язків в нейронній мережі [8]. Видалення слабких зв'язків приведе до збільшення узагальнюючих властивостей нейромережі. Для видалення зв'язку достатньо для відповідного вагового коефіцієнта задати нульове значення. Отже, для проведення контрастування нейронної мережі необхідно для всіх вагових коефіцієнтів , де $\mathrm{i}=1 . . \mathrm{I}-1$, j=1..J, k=1, ..., K, задати нульове значення. Тут I - кількість шарів нейронної мережі, J - кількість нейронів і шару, К - кількість нейронів i+1 шару, Р - порогове значення для вагових коефіцієнтів [8].

Відбір інформаційних ознак

Для збільшення точності моделі, побудованої на основі гібридної нейромережі із коригувальним блоком, доцільно виконувати відбір інформативних ознак.

Відбір інформативних ознак пропонується здійснювати шляхом послідовного видалення найменш інформативних ознак [9], доки помилка нейронної мережі не збільшиться від чергового видалення ознаки. Для прискорення відбору доцільно використовувати зменшену кількість епох навчання та не використовувати коригувальну нейронну мережу.

Метод відбору інформативних ознак полягає у послідовному виконанні таких етапів.

Етап ініціалізації. Розділити навчальну вибірку даних $<\mathrm{x}, \mathrm{y}>$ на $\mathrm{N}$ рівних частин, $\mathrm{N}>2$. Провести навчання та тестування нейронної мережі $\mathrm{N}$ разів, в якості тестової вибірки використовувати $\mathrm{n}$ частину вибірки, а всі інші - в якості навчальної, n=1..N. Визначити помилки моделей En, визначити загальну помилку Ез за формулою:

$$
E_{3}=\frac{1}{N-2}\left(\sum_{n=1}^{N} E_{n}-E_{\text {max }}-E_{\text {min }}\right)
$$

де Emax та Emin - максимальне та мінімальне значення помилки для побудованих моделей.

Етап пошуку неінформативних ознак. Для $\mathrm{X}=1 . . \mathrm{X}$, де $\mathrm{X}$ - загальна кількість ознак: провести навчання та тестування нейронної мережі $\mathrm{N}$ разів, не враховуючи ознаку х. Визначити загальні помилки Езх.

Серед помилок Езх знайти мінімальну помилку Emin. Якщо Emin<E3, видалити ознаку х з набору вхідних ознак, задати Eз=Emin, повторити етап пошуку неінформативних ознак; у протилежному випадку - завершити відбір інформативних ознак, провести навчання моделі на повній навчальній вибірці з використанням вхідних ознак, які залишилися [9].

Експерименти та результати

Для перевірки працездатності запропонованих архітектури нейромережі та метода піi побудови розроблено програмне забезпечення мовою С\#. Програмне забезпечення дозволяє виконувати побудову нейронних мереж та їх навчання на заданій вибірці даних.

За допомогою розробленого програмного забезпечення було побудовано моделі залежностей параметрів авіаційних двигунів для різних режимів випробувань (визначення прохідного перерізу міжлопаткової решітки соплових апаратів виконувалося методом проливки рідиною): ntk - кількість обертів турбіни компресора, Т3 температура газу перед турбіною, Gt - витрати газу через турбіну, tвх - температура на вході в двигун, Nст - кількість ступенів, $\alpha \mathrm{BHA}$ - кут установки лопаток вхідного направляючого апарату, Nпр - наведена потужність, Gв - витрати повітря, $\pi$ - ступень стиснення повітря - у режимах «злітний» та «2 крейсерський» від тих же параметрів у режимах «номінальний» та «1 крейсерський», а також від прохідних перетинів соплових апаратів (CA1, CA2, CA3, CA4) i висот лопаток (Во) [1]. Фрагмент навчальної вибірки наведено у табл. 1-4.

Кожна 3 побудованих моделей складається 3 двох чотиришарових нейронних мереж. В першій мережі є 23 нейрони на вхідному шарі, 32 - на першому прихованому шарі, 32 - на другому прихованому шарі, 1 - на вихідному шарі. В 
http://www.atbp.onaft.edu.ua/

другій мережі $є 24$ нейрони на вхідному шарі, 32 - на першому прихованому шарі, 32 - на другому прихованому шарі, 1 - на вихідному шарі. Функція активації нейронів прихованих шарів в обох нейронних мережах задається як . Функція активації нейронів вихідного шару задається як . В першій нейронній мережі є 88 нейронів та 1857 вагових коефіцієнтів, в другій - 89 нейронів та 1889 вагових коефіцієнтів.

Таблиця 1 - Фрагмент навчальної вибірки даних для режиму «номінальний»

\begin{tabular}{|c|c|c|c|c|c|c|c|c|c|c|c|c|c|c|}
\hline$s$ & $n_{t k}$ & $T_{3}$ & $G_{t}$ & $T_{6 x}$ & $N_{c m}$ & $\alpha_{B H A}$ & $N_{n p}$ & $G_{6}$ & $\pi_{k}$ & $B_{o}$ & $C A 1$ & $C A 2$ & $C A 3$ & $C A 4$ \\
\hline 1 & 95,17 & 812,1 & 379,2 & $-4,8$ & 99,22 & 6,1 & 1760,2 & 8,34 & 8 & 763,5 & 34,86 & 54,8 & 98,4 & 102,19 \\
\hline 2 & 95,03 & 873,3 & 379,6 & 0,7 & 99,79 & 6 & 1753,6 & 8,3 & 7,96 & 763 & 34,66 & 55,61 & 98,4 & 102,8 \\
\hline 3 & 95,48 & 835,7 & 392,8 & $-1,7$ & 100,01 & 5,8 & 1742,1 & 8,46 & 7,86 & 764,5 & 34,66 & 55,49 & 99,15 & 103,57 \\
\hline 4 & 95,23 & 830,3 & 387,6 & 10,6 & 100 & 6,9 & 1720 & 8,41 & 7,75 & 746 & 34,88 & 54,35 & 99,05 & 103,57 \\
\hline 5 & 95,02 & 820,8 & 382,3 & 11,2 & 98,81 & 7 & 1731,8 & 8,35 & 7,75 & 743,5 & 34,88 & 54,98 & 98,4 & 102,5 \\
\hline 6 & 95,31 & 824,8 & 384,8 & 10,8 & 99,84 & 5,8 & 1719,7 & 8,48 & 8,04 & 762 & 34,88 & 54,83 & 99,15 & 103,37 \\
\hline 7 & 95,21 & 818,5 & 382,3 & 13,3 & 98,29 & 5,8 & 1725,8 & 8,45 & 7,98 & 762,5 & 34,88 & 54,35 & 98,66 & 101,84 \\
\hline 8 & 95,27 & 792,5 & 385,6 & 14,6 & 98,61 & 6,8 & 1727,3 & 8,09 & 7,98 & 757 & 34,8 & 54,41 & 98,95 & 103,47 \\
\hline
\end{tabular}

Таблиця 2 - Фрагмент навчальної вибірки даних для режиму «злітний»

\begin{tabular}{|c|c|c|c|c|c|c|c|c|c|c|c|c|c|c|}
\hline$s$ & $n_{t k}$ & $T_{3}$ & $G_{t}$ & $T_{6 x}$ & $N_{c m}$ & $\alpha_{B H A}$ & $N_{n p}$ & $G_{6}$ & $\pi_{\kappa}$ & $B_{o}$ & $C A 1$ & $C A 2$ & $C A 3$ & $C A 4$ \\
\hline 1 & 98,8 & 884,4 & 468 & $-4,9$ & 98,2 & 2 & 2305,5 & 9,17 & 9,1 & 763,5 & 34,86 & 54,8 & 98,4 & 102,19 \\
\hline 2 & 97,86 & 913,1 & 467,4 & 0,2 & 98,17 & 0,9 & 2420,8 & 9,27 & 9,26 & 763 & 34,66 & 55,61 & 98,4 & 102,8 \\
\hline 3 & 98,13 & 906,9 & 480,9 & $-2,1$ & 98,5 & $-0,2$ & 2486,8 & 9,56 & 9,31 & 764,5 & 34,66 & 55,49 & 99,15 & 103,57 \\
\hline 4 & 97,9 & 905 & 471,8 & 10,6 & 97,76 & 2,1 & 2342,2 & 9,35 & 8,98 & 746 & 34,88 & 54,35 & 99,05 & 103,57 \\
\hline 5 & 97,64 & 895,2 & 465,3 & 10,9 & 97,91 & 1,4 & 2423,3 & 9,39 & 9,18 & 743,5 & 34,88 & 54,98 & 98,4 & 102,5 \\
\hline 6 & 98,15 & 904,5 & 471,1 & 11,2 & 97,6 & 1,2 & 2306,3 & 9,37 & 9,18 & 762 & 34,88 & 54,83 & 99,15 & 103,37 \\
\hline 7 & 97,77 & 895 & 468,8 & 13,8 & 97,85 & 0,8 & 2353,4 & 9,38 & 9,23 & 762,5 & 34,88 & 54,35 & 98,66 & 101,84 \\
\hline 8 & 98,08 & 895,9 & 467,8 & 14,7 & 98,04 & 3,3 & 2231,3 & 8,8 & 8,94 & 757 & 34,8 & 54,41 & 98,95 & 103,47 \\
\hline
\end{tabular}

Таблиця 3 - Фрагмент навчальної вибірки даних для режиму «1 крейсерський»

\begin{tabular}{|c|c|c|c|c|c|c|c|c|c|c|c|c|c|c|}
\hline$s$ & $n_{t k}$ & $T_{3}$ & $G_{t}$ & $T_{6 x}$ & $N_{c m}$ & $\alpha_{B H A}$ & $N_{n p}$ & $G_{6}$ & $\pi_{k}$ & $B_{o}$ & $C A 1$ & $C A 2$ & $C A 3$ & $C A 4$ \\
\hline 1 & 93,86 & 783,5 & 343,7 & $-4,7$ & 99,24 & 8,1 & 1566,4 & 8,02 & 7,59 & 763,5 & 34,86 & 54,8 & 98,4 & 102,19 \\
\hline 2 & 93,72 & 806,9 & 344,5 & 0,6 & 99,65 & 7,7 & 1572,2 & 8 & 7,56 & 763 & 34,66 & 55,61 & 98,4 & 102,8 \\
\hline 3 & 94,26 & 807,2 & 357,5 & $-1,5$ & 99,3 & 7,7 & 1538,7 & 8,11 & 7,44 & 764,5 & 34,66 & 55,49 & 99,15 & 103,57 \\
\hline 4 & 94,06 & 800,4 & 354 & 10,6 & 99,58 & 8,6 & 1510,6 & 8,06 & 7,32 & 746 & 34,88 & 54,35 & 99,05 & 103,57 \\
\hline 5 & 93,85 & 791 & 349,1 & 10,7 & 98,49 & 8,5 & 1554,7 & 8,04 & 7,38 & 743,5 & 34,88 & 54,98 & 98,4 & 102,5 \\
\hline 6 & 94 & 793 & 350,3 & 10,3 & 99,62 & 7,4 & 1535 & 8,15 & 7,6 & 762 & 34,88 & 54,83 & 99,15 & 103,37 \\
\hline 7 & 94 & 787,9 & 347,6 & 13 & 98,84 & 7,9 & 1521,8 & 8,09 & 7,53 & 762,5 & 34,88 & 54,35 & 98,66 & 101,84 \\
\hline 8 & 93,96 & 763,2 & 352,7 & 14,2 & 98,65 & 8,6 & 1521,6 & 7,75 & 7,56 & 757 & 34,8 & 54,41 & 98,95 & 103,47 \\
\hline
\end{tabular}


http://www.atbp.onaft.edu.ua/

Таблиця 4 - Фрагмент навчальної вибірки даних для режиму «2 крейсерський»

\begin{tabular}{|c|c|c|c|c|c|c|c|c|c|c|c|c|c|c|}
\hline$s$ & $n_{t k}$ & $T_{3}$ & $G_{t}$ & $T_{b x}$ & $N_{c m}$ & $\alpha_{B H A}$ & $N_{n p}$ & $G_{6}$ & $\pi_{\kappa}$ & $B_{o}$ & $C A 1$ & $C A 2$ & $C A 3$ & $C A 4$ \\
\hline 1 & 91,7 & 793,9 & 290,5 & $-4,5$ & 99,44 & 10,7 & 1283,8 & 7,51 & 6,96 & 763,5 & 34,86 & 54,8 & 98,4 & 102,19 \\
\hline 2 & 91,56 & 761,4 & 291,8 & 0,2 & 99,42 & 10,8 & 1274,6 & 7,45 & 6,9 & 763 & 34,66 & 55,61 & 98,4 & 102,8 \\
\hline 3 & 92,35 & 764,5 & 304,6 & $-2,2$ & 99,8 & 10,8 & 1255,6 & 7,56 & 6,8 & 764,5 & 34,66 & 55,49 & 99,15 & 103,57 \\
\hline 4 & 92,21 & 755,5 & 303,5 & 11,4 & 99,16 & 11,4 & 1239 & 7,55 & 6,73 & 746 & 34,88 & 54,35 & 99,05 & 103,57 \\
\hline 5 & 91,96 & 746,4 & 299,3 & 10,6 & 99,44 & 11,3 & 1249,1 & 7,48 & 6,75 & 743,5 & 34,88 & 54,98 & 98,4 & 102,5 \\
\hline 6 & 91,84 & 745,2 & 298,5 & 10,8 & 100,01 & 10,4 & 1235,3 & 7,61 & 6,92 & 762 & 34,88 & 54,83 & 99,15 & 103,37 \\
\hline 7 & 92 & 741,9 & 295,7 & 13 & 99,77 & 11,4 & 1207,5 & 7,49 & 6,82 & 762,5 & 34,88 & 54,35 & 98,66 & 101,84 \\
\hline 8 & 91,79 & 719,2 & 303,4 & 14,2 & 98,06 & 11,4 & 1240,7 & 7,23 & 6,92 & 757 & 34,8 & 54,41 & 98,95 & 103,47 \\
\hline
\end{tabular}

Навчання і тестування кожної з моделей проводиться незалежно від інших. В кожній моделі спочатку навчається перша нейромережа, після чого проводиться ії тестування. Далі результати ії роботи додаються до вхідних параметрів навчальної та тестувальної вибірок, і проводиться навчання коригуючої нейронної мережі. Після цього проводиться тестування коригувальної нейромережі.

Параметри навчання задавалися у такий спосіб: кількість епох навчання -800 , крок навчання $-0,05$. Після кожної епохи екземпляри навчальної вибірки перемішуються випадковим чином, крок навчання до 250 епохи помножується на 1,01 , після - помножується на 0,99. Послідовне збільшення кроку навчання на початку навчання зроблено для підвищення швидкості навчання, а поступове зменшення кроку навчання наприкінці процесу навчання зроблено для підвищення точності навчання.

На рис. 2 зображено графіки залежності середньоквадратичної помилки від кількості епох навчання для першої та коригуючої нейронних мереж.

У результаті проведених обчислювальних експериментів побудовано моделі залежностей параметрів авіаційних двигунів у режимах «злітний» та «2 крейсерський» від параметрів у режимах «номінальний» та «1 крейсерський», а також від прохідних перетинів соплових апаратів і висот лопаток.

У таблицях 5-6 наведено фрагмент отриманих результатів - реальні та розрахункові значення вихідних параметрів моделей (мод. 1 - без коригувальної нейромережі, мод. 2 - 3 коригувальною нейромережею). Всі дані вказано у нормованому вигляді.

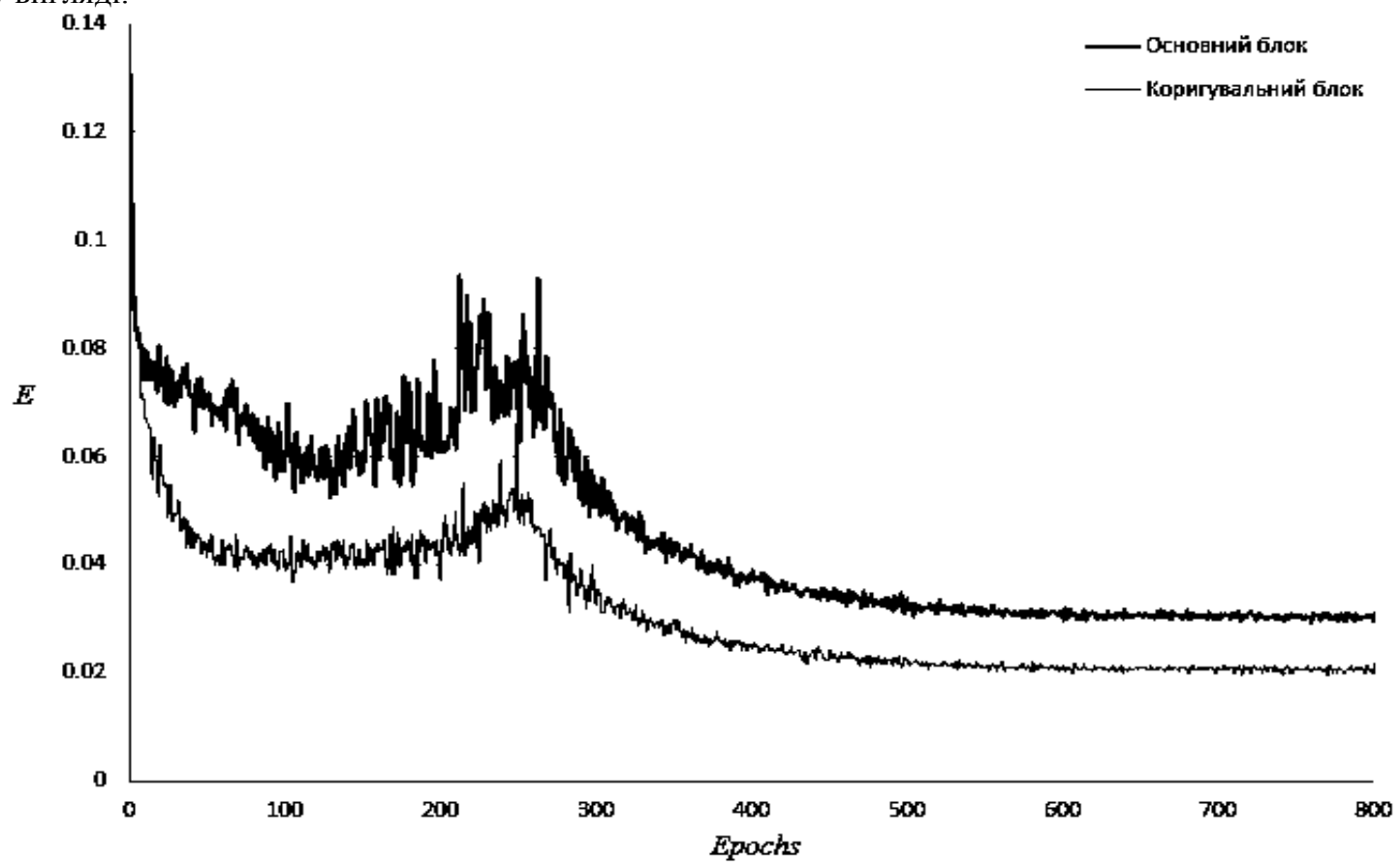

Рис. 2 - Графіки залежності помилки від кількості епох навчання 
Автоматизація технологічних і бізнес-процесів Volume 10, Issue 1 /2018

http://www.atbp.onaft.edu.ua/

Таблиця 5 - Результати експериментів для параметра витрати газу через турбіну Gt

\begin{tabular}{|c|c|c|c|c|c|c|c|c|c|c|}
\hline & \multicolumn{5}{|c|}{ Злітний } & \multicolumn{5}{|c|}{2 крейсерський } \\
\hline$s$ & Реал. & Мод. 1 & Мод. 2 & $\begin{array}{r}\text { Відносна } \\
\text { помилка } 1\end{array}$ & $\begin{array}{r}\text { Відносна } \\
\text { помилка } 2\end{array}$ & Реал. & Мод. 1 & Мод. 2 & $\begin{array}{r}\text { Відносна } \\
\text { помилка } 1\end{array}$ & $\begin{array}{r}\text { Відносна } \\
\text { помилка } 2\end{array}$ \\
\hline 1 & 0,19 & 0,44 & 0,33 & 0,24 & 0,13 & 0,61 & 0,43 & 0,51 & 0,18 & 0,1 \\
\hline 2 & 0,72 & 0,62 & 0,66 & 0,1 & 0,06 & 0,53 & 0,65 & 0,61 & 0,12 & 0,08 \\
\hline 3 & 0,33 & 0,44 & 0,4 & 0,1 & 0,06 & 0,45 & 0,34 & 0,38 & 0,11 & 0,07 \\
\hline 4 & 0,19 & 0,09 & 0,17 & 0,1 & 0,02 & 0,33 & 0,28 & 0,31 & 0,06 & 0,03 \\
\hline 5 & 0,67 & 0,67 & 0,7 & 0,01 & 0,03 & 0,65 & 0,58 & 0,6 & 0,07 & 0,05 \\
\hline 6 & 0,89 & 0,75 & 0,81 & 0,14 & 0,08 & 0,76 & 0,7 & 0,72 & 0,07 & 0,04 \\
\hline 7 & 0,56 & 0,6 & 0,59 & 0,05 & 0,04 & 0,61 & 0,5 & 0,53 & 0,11 & 0,07 \\
\hline 8 & 0,44 & 0,38 & 0,41 & 0,07 & 0,03 & 0,49 & 0,3 & 0,36 & 0,19 & 0,13 \\
\hline 9 & 0,75 & 0,76 & 0,76 & 0,01 & 0,01 & 0,69 & 0,73 & 0,72 & 0,04 & 0,03 \\
\hline 10 & 0,67 & 0,76 & 0,74 & 0,09 & 0,07 & 0,84 & 0,8 & 0,82 & 0,04 & 0,03 \\
\hline 11 & 0,39 & 0,43 & 0,4 & 0,04 & 0,01 & 0,25 & 0,26 & 0,27 & 0,01 & 0,02 \\
\hline 12 & 0,69 & 0,75 & 0,74 & 0,06 & 0,04 & 0,84 & 0,73 & 0,76 & 0,12 & 0,08 \\
\hline 13 & 0,53 & 0,54 & 0,53 & 0,01 & 0 & 0,49 & 0,42 & 0,46 & 0,07 & 0,03 \\
\hline 14 & 0,64 & 0,57 & 0,58 & 0,07 & 0,06 & 0,57 & 0,52 & 0,54 & 0,05 & 0,03 \\
\hline 15 & 0,78 & 0,53 & 0,61 & 0,25 & 0,17 & 0,49 & 0,53 & 0,52 & 0,04 & 0,03 \\
\hline 16 & 0,61 & 0,46 & 0,49 & 0,15 & 0,12 & 0,25 & 0,35 & 0,33 & 0,1 & 0,07 \\
\hline 17 & 0,75 & 0,63 & 0,68 & 0,12 & 0,07 & 0,53 & 0,52 & 0,53 & 0,01 & 0,01 \\
\hline 18 & 0,64 & 0,59 & 0,61 & 0,05 & 0,03 & 0,61 & 0,53 & 0,56 & 0,07 & 0,05 \\
\hline 19 & 0,81 & 0,79 & 0,8 & 0,01 & 0 & 0,8 & 0,78 & 0,78 & 0,02 & 0,02 \\
\hline 20 & 0,83 & 0,7 & 0,76 & 0,14 & 0,08 & 0,69 & 0,66 & 0,67 & 0,03 & 0,02 \\
\hline 21 & 0,78 & 0,77 & 0,75 & 0 & 0,03 & 0,61 & 0,74 & 0,7 & 0,13 & 0,09 \\
\hline 22 & 0,33 & 0,39 & 0,37 & 0,06 & 0,04 & 0,29 & 0,22 & 0,24 & 0,08 & 0,06 \\
\hline 23 & 0,78 & 0,72 & 0,74 & 0,06 & 0,04 & 0,53 & 0,52 & 0,53 & 0,01 & 0 \\
\hline 24 & 0,72 & 0,79 & 0,77 & 0,07 & 0,05 & 0,8 & 0,8 & 0,81 & 0 & 0 \\
\hline 25 & 0,67 & 0,73 & 0,7 & 0,06 & 0,04 & 0,92 & 0,79 & 0,84 & 0,14 & 0,08 \\
\hline \multicolumn{4}{|c|}{ Середн. арифм. } & 0,08 & 0,06 & & & & 0,07 & 0,05 \\
\hline
\end{tabular}

Таблиця 6 - Результати експериментів для параметра витрати повітря $G_{\text {в }}$

\begin{tabular}{|c|c|c|c|c|c|c|c|c|c|c|}
\hline & \multicolumn{5}{|c|}{ Злітний } & \multicolumn{5}{|c|}{2 крейсерський } \\
\hline$s$ & Реал. & Мод. 1 & Мод. 2 & $\begin{array}{c}\text { Відносна } \\
\text { помилка } 1\end{array}$ & $\begin{array}{c}\text { Відносна } \\
\text { помилка } 2\end{array}$ & Реал. & Мод. 1 & Мод. 2 & $\begin{array}{c}\text { Відносна } \\
\text { помилка } 1\end{array}$ & $\begin{array}{c}\text { Відносна } \\
\text { помилка } 2\end{array}$ \\
\hline 1 & 0,35 & 0,53 & 0,46 & 0,18 & 0,11 & 0,69 & 0,51 & 0,51 & 0,18 & 0,18 \\
\hline 2 & 0,45 & 0,4 & 0,42 & 0,05 & 0,03 & 0,79 & 0,72 & 0,69 & 0,06 & 0,1 \\
\hline 3 & 0,41 & 0,3 & 0,34 & 0,11 & 0,07 & 0,75 & 0,72 & 0,71 & 0,03 & 0,04 \\
\hline 4 & 0,41 & 0,34 & 0,37 & 0,07 & 0,04 & 0,77 & 0,54 & 0,6 & 0,23 & 0,18 \\
\hline 5 & 0,37 & 0,6 & 0,55 & 0,23 & 0,19 & 0,45 & 0,52 & 0,49 & 0,06 & 0,04 \\
\hline 6 & 0,66 & 0,49 & 0,55 & 0,17 & 0,11 & 0,51 & 0,6 & 0,54 & 0,09 & 0,03 \\
\hline 7 & 0,41 & 0,6 & 0,55 & 0,19 & 0,14 & 0,73 & 0,53 & 0,59 & 0,2 & 0,15 \\
\hline 8 & 0,37 & 0,48 & 0,45 & 0,11 & 0,07 & 0,79 & 0,72 & 0,74 & 0,07 & 0,05 \\
\hline 9 & 0,07 & 0,26 & 0,2 & 0,19 & 0,13 & 0,17 & 0,18 & 0,25 & 0,01 & 0,08 \\
\hline 10 & 0,36 & 0,48 & 0,44 & 0,12 & 0,09 & 0,48 & 0,24 & 0,31 & 0,24 & 0,17 \\
\hline 11 & 0,44 & 0,44 & 0,44 & 0,01 & 0 & 0,56 & 0,41 & 0,44 & 0,15 & 0,13 \\
\hline 12 & 0,34 & 0,53 & 0,48 & 0,19 & 0,14 & 0,61 & 0,37 & 0,43 & 0,23 & 0,18 \\
\hline 13 & 0,34 & 0,57 & 0,5 & 0,23 & 0,16 & 0,56 & 0,4 & 0,39 & 0,16 & 0,18 \\
\hline 14 & 0,41 & 0,42 & 0,42 & 0,01 & 0,01 & 0,59 & 0,41 & 0,44 & 0,18 & 0,16 \\
\hline 15 & 0,4 & 0,47 & 0,45 & 0,07 & 0,05 & 0,61 & 0,46 & 0,45 & 0,14 & 0,16 \\
\hline 16 & 0,49 & 0,51 & 0,51 & 0,02 & 0,02 & 0,66 & 0,4 & 0,48 & 0,26 & 0,18 \\
\hline 17 & 0,16 & 0,21 & 0,19 & 0,05 & 0,04 & 0,46 & 0,44 & 0,44 & 0,02 & 0,03 \\
\hline 18 & 0,33 & 0,43 & 0,4 & 0,1 & 0,07 & 0,77 & 0,64 & 0,65 & 0,13 & 0,12 \\
\hline 19 & 0,49 & 0,53 & 0,52 & 0,04 & 0,03 & 0,82 & 0,69 & 0,73 & 0,13 & 0,09 \\
\hline 20 & 0,45 & 0,5 & 0,5 & 0,05 & 0,04 & 0,8 & 0,69 & 0,75 & 0,12 & 0,05 \\
\hline 21 & 0,37 & 0,37 & 0,36 & 0,01 & 0 & 0,7 & 0,63 & 0,65 & 0,07 & 0,06 \\
\hline 22 & 0,25 & 0,3 & 0,29 & 0,05 & 0,04 & 0,51 & 0,6 & 0,64 & 0,09 & 0,13 \\
\hline 23 & 0,3 & 0,43 & 0,38 & 0,13 & 0,09 & 0,63 & 0,63 & 0,6 & 0,01 & 0,04 \\
\hline 24 & 0,33 & 0,26 & 0,29 & 0,07 & 0,04 & 0,76 & 0,64 & 0,7 & 0,12 & 0,06 \\
\hline 25 & 0,23 & 0,24 & 0,24 & 0,02 & 0,01 & 0,65 & 0,62 & 0,61 & 0,03 & 0,04 \\
\hline \multicolumn{4}{|c|}{ Середн. арифм. } & 0,1 & 0,07 & & & & 0,12 & 0,1 \\
\hline
\end{tabular}


Як видно 3 таблиць 5-6, запропонований метод дозволяє будувати більш прийнятні моделі на основі багатошарових нейронних мереж (середньоквадратичні помилки нижче ніж в моделях, побудованих на основі однієї нейронної мережі) оскільки використовується нейронна мережа для корекції результатів роботи першої нейромережі. Розроблений метод забезпечив помилку на тестовій вибірці від 0,01 до 0,1 в залежності від типу параметра, що в середньому на 30\% менше, ніж помилка, отримана за допомогою однієї нейронної мережі. Загальний час навчання при цьому збільшився у 2 рази.

Таким чином, результати порівняльного аналізу показали, що, не зважаючи на збільшення часу роботи, точність запропонованого метода є більш високою, ніж точність однієї нейронної мережі. При цьому збільшення часу навчання звичайної нейромережі не приведе до збільшення точності.

Висновки

У роботі вирішено актуальну задачу скорочення часу та зменшення вартості проведення випробувань авіаційних двигунів шляхом побудови нейромоделей залежності параметрів двигунів у різних режимах роботи.

Наукова новизна роботи полягає у тому, що запропоновано метод побудови глибоких нейронних мереж прямого поширення, який використовує коригувальну нейронну мережу для покращення результатів роботи звичайної нейромережі. При цьому кожна 3 нейронних мереж навчається окремо, що дозволяє спростити та прискорити процес навчання.

Практична цінність отриманих результатів полягає у тому, що: розроблено програмне забезпечення, яке реалізує запропонований метод і дозволяє виконувати побудову нейронних мереж, їх навчання та тестування на вибірках даних; вирішено практичне завдання визначення параметрів авіаційних двигунів при проведені їх випробувань.

Перспективи подальших досліджень полягають у визначенні оптимальних параметрів нейронних мереж, а саме: кількості шарів, кількості нейронів на кожному шарі, функцій активації нейронів, кількості епох навчання; а також у застосуванні запропонованого методу на більш широкому класі задач.

\section{Referenses}

[1] V. Boguslaev, Al. A. Oleynik, An. A. Oleynik, D. V. Pavlenko, and S. A. Subbotin, Progressivnyie tehnologii modelirovaniya, optimizatsii $i$ intellektualnoy avtomatizatsii etapov zhiznennogo tsikla aviatsionnyih dvigateley : monografiya. Zaporozhye : Motor Sich, 2009.

[2] V. I. Dubrovin, S. A. Subbotin, A. V. Boguslaev, and V. K. Yatsenko, Intellektualnyie sredstva diagnostiki $i$ prognozirovaniya nadezhnosti aviadvigateley : monografiya. - Zaporozhye: Motor-Sich, 2003.

[3] O. H. Rudenko, and Ie. V. Bodianskyi, Shtuchni neironni merezhi. Kharkiv: Kompaniia SMIT, 2006.

[4] S. Haykin, Neyronnyie seti: polnyiy kurs. Moskva: Vilyams, 2006.

[5] M. Bishop, Pattern recognition and machine learning. Berlin: Springer, 2006.

[6] S. J. Russell, Artificial intelligence: a modern approach. London: Pearson, 2010.

[7] Optimization: Stochastic Gradient Descent [Online]. Available: http://cs231n.github.io/optimization-1

[8] Optimalnoe prorezhivanie neyronnyih setey [Online]. Available: http://www.machinelearning.ru/wiki/ index.php?title=Оптимальное_прореживание_нейронных_сетей

[9] P. Melin, O.R. Castillo, E.G. Ramirez, and J. Kacprzyk. Analysis and design of intelligent systems using soft computing techniques. Berlin: Springer,2007. - 855 p.

\section{Література}

[1] Богуслаев А. В., Олейник Ал. А., Олейник Ан. А., Павленко Д. В., Субботин С. А. Прогрессивные технологии моделирования, оптимизации и интеллектуальной автоматизации этапов жизненного цикла авиационных двигателей : монография. Запорожье : Мотор Сич, 2009. 468 с.

[2] Дубровин В. И., Субботин С. А., Богуслаев А.В., Яценко В. К. Интеллектуальные средства диагностики и прогнозирования надежности авиадвигателей: монография. Запорожье: Мотор-Сич, 2003. 279 с.

[3] Руденко О. Г., Бодянський С. В. Штучні нейронні мережі. Харків: Компанія СМIT, 2006. 404 с.

[4] Хайкин С. Нейронные сети: полный курс. Москва: Вильямс, 2006. 1104 с.

[5] Bishop C. M. Pattern recognition and machine learning. Berlin: Springer, 2006. 738 p.

[6] Russell S. J. Artificial intelligence: a modern approach. London: Pearson, 2010. 1152 p.

[7] Optimization: Stochastic Gradient Descent [Electronic resource]. Access mode: http://cs231n.github.io/optimization-1

[8] Оптимальное прореживание нейронных сетей [Электронный ресурс]. Режим доступа: http://www.machinelearning.ru/wiki/index.php?title=Оптимальное_прореживание_нейронных_сетей

[9] Melin P., Castillo O.R., Ramirez E.G., Kacprzyk J. Analysis and design of intelligent systems using soft computing techniques. Berlin: Springer, 2007. 855 p. 